Mitteilungen der Österreichischen Geographischen Gesellschaft, 162. Jg., S. 469-494

(Annals of the Austrian Geographical Society, Vol. 162, pp. 469-494)

Wien (Vienna) 2020, https://doi.org/10.1553/moegg162s469

\title{
The Socio-Spatial Aspect of Rurality - A Case Study of Rural Settlements in Central Serbia
}

\author{
Marija DrobNJAKOviĆ, Belgrade [Beograd] and Jovana ČıIIĆ, Novi Sad* \\ Initial submission / erste Einreichung: 07/2019; revised submission / revidierte Fassung: 06/2020; \\ final acceptance / endgültige Annahme: 09/2020
}

with 3 figures and 3 tables in the text

\section{CONTENTS}

Summary 469

Zusammenfassung

1 Introduction

2 Defining and measuring rurality in (Central) Serbia - between success and constraints.

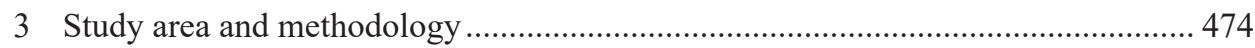

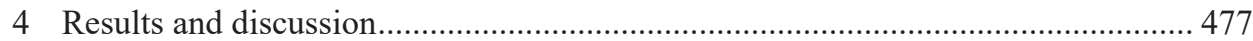

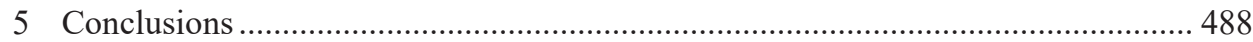

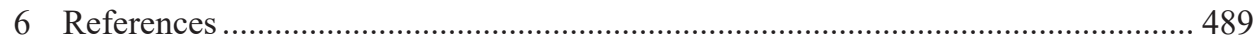

\section{Summary}

Contemporary rural areas have been significantly changed. Thus, previous rural typologies are no longer valid and there is a need for developing and standardising new measures of rurality. We developed a set of 23 rural indicators which were tested on data on the characteristics of rural areas in contemporary Serbian society. Based on statistical analyses, four variables were excluded and three main rural attributes were confirmed (population change, economic dependency ratio, population density in the built-up area). The reduced set of 19 variables could be a relevant platform for establishing a rural typology in Central Serbia, but also for conducting precise analyses of the transformation of rural areas in similar post-socialist societies.

Keywords: Rural indicators, rural settlements, rurality, statistical analysis, Central Serbia

\footnotetext{
* Marija DrobNJAKović, research associate, Geographical Institute "Jovan Cvijić", Serbian Academy of Science and Arts, Đura Jakšić 8, 11000 Belgrade, Republic of Serbia; Jovana ČIKIĆ (corresponding author), associate professor, University of Novi Sad, Faculty of Philosophy, Department of Sociology, Zoran Đinđić 2, 21000 Novi Sad, Republic of Serbia. -Emails: m.drobnjakovic@gi.sanu.ac.rs, jovana.cikic@ff.uns.ac.rs.
} 


\section{Zusammenfassung}

\section{SOZIALRÄUMLICHE ASPEKTE VON RURALITÄT - EINE FALLSTUdIE ÜBER LÄNDLICHE SIEDLUNGEN IN ZENTRALSERBIEN}

Die ländlichen Räume haben sich in letzter Zeit erheblich verändert. Bisherige ländliche Typologien sind daher nicht mehr gültig und es besteht die Notwendigkeit, neue Konzepte und Methoden für die Analyse des ländlichen Raums zu entwickeln und zu standardisieren. Wir haben 23 ländliche Indikatoren entwickelt, die anhand von empirischen Daten über die Merkmale ländlicher Gebiete in der heutigen serbischen Gesellschaft getestet wurden. Basierend auf statistischen Analysen wurden vier Variablen ausgeschlossen und drei ländliche Hauptindikatoren bestätigt (Bevölkerungsveränderung, wirtschaftlicher Abhängigkeitsgrad, Bevölkerungsdichte im bebauten Gebiet). Ein reduzierter Satz von 19 Variablen könnte eine relevante Plattform für die Etablierung einer Typologie der ländlichen Siedlungen in Zentralserbien sein, aber auch für die Durchführung präziser Analysen der Transformation ländlicher Räume in ähnlichen postsozialistischen Gesellschaften.

Schlagwörter: Ländliche Indikatoren, ländliche Siedlungen, Ruralität, statistische Analyse, Zentralserbien

\section{Introduction}

To define rural or rurality, identify its main features and establish a relevant rural typology has major significance for both academia and planning practice, as well. However, there is neither a single definition of rural nor rurality (HALFRACREE 1993; MURDOCH and Pratt 1993; PAQueTte and Domon 2003; Lukić 2012). The meaning of rural and rurality has been changing in accordance with the social, economic, cultural, political, and environmental circumstances, ranging from the urban-rural dichotomy through the urban-rural continuum and the urban-rural partnership to the negation of rurality (cf. OPENSHAW 1985; Zlatić 1993; Hoggart, Buller and Black 1995; Harrington and O'Donoghue 1998; Bengs and Schmidt-Thome 2003; Woods 2005, 2012; Cloke 2006; VAsilevska 2006; GALlent et al. 2008; Lukić 2010; Tošić 2011; Mitrović 2015). Also, there is a great subjectivity in understanding rural and rurality caused by the specific social circumstances, personal affinities and prevailing media image (PHILLIPS, FisH and AGG 2001). In addition, the comprehension of rural and rurality is influenced by different discourse at the time. As Woods (2011) wrote, various discourses (political, academic, everyday life, economic, media) are ways to find out about rural and rurality. The more influence a discourse has, the more hegemonic understanding of rural and rurality is (ČIKIĆ 2017).

Thus, it is very difficult to establish a generally accepted set of rural indicators. Various criteria have been used for defining and measuring rural and rurality, depending on the characteristics of the observed area or observed period of time. Also, even though quite important, some rural indicators are difficult to analyse statistically (e.g. life quality incomparable data due to different data collection methodologies). The identification of rural indicators usually takes place at the national level. Some countries (e.g. England and 
Wales, Bulgaria, Hungary, Czech Republic) apply official/census rural definitions and indicators, such as population density or a prescribed population-size threshold of the settlements (OECD 1994; Eurostat 2010). Others rely on modified approaches adjusted to their local rural features (e.g. Romania), while some countries strictly adhere to administrative units (e.g. Germany, Serbia).

Different thresholds of the chosen rural indicators, variable data availability and different levels of the spatial analysis (e.g. address, settlement, municipality, and region) are obvious and cause trouble in cross-national analyses. The aforementioned indicates that a uniqe list of rural indicators and threshold values has not yet been established, despite the current tendency to harmonise them at the EU level (e.g. OECD 1994; European Commission 1997; The Wye Group 2007). Nevertheless, there are several disadvantages in the mentioned methodologies - they refer to poor data availability for the same spatial unit/ level and incompatible national methodologies for data collecting. The arbitrary character of the selected rural indicators which affects their value is also disputable (CLOKE 2006). In fact, there is a discussion at the EU level on the selection of relevant rural indicators, their consistency and the degree to which they reflect the local rural features, especially in (post)transitional societies.

Consequently, it is difficult to create a comprenhensive rural typology. Such is even harder if we take into consideration the diversity of rural regions and settlements, such as in contemporary Serbian society. Nevertheless, despite the mosaic of various rural characteristics and types of rural settlement, the official Serbian census methodology does not even recognise rural settlement per se nor use any typology of rural areas. Accordingly, both academians and planning practicioners lack a significant methodological tool and referential data.

The main research problem hereby is to identify criteria for defining rural settlements. We establish such criteria based on the analysis of total scope of rural settlements in the region of Central Serbia. Setting the critieria list could be valuable for establishing a national rural typology, but also for comparison with other, currently available rural indicators in similar profile countries and the EU.

\section{Defining and measuring rurality in (Central) Serbia - between success and constraints}

Research of rural areas in Central Serbia has two major characteristics - it has often been a part of wider research of rural areas and it has a longstanding tradition. In the first case, defining, measuring and analysing rural areas in Central Serbia was usually a segment in researching rural Serbian or even rural Balkan areas, in general (KARADŽIĆ 1827; CviJIĆ 1922; KoJić 1958; Radmanović 1999; CveJić et al. 2010). Particulary the central part of Serbia was considered as a representative for the investigation of rurality in Serbia with all its diversity, while the northern part of the country was annexed after the First World War and is characterised by a uniform and planned structure of rural settlements. Consequently, efforts in researching rural areas in Central Serbia and Serbia are intertwined and mutually dependent, both in methodology and observed trends. Secondly, a longstanding tradition of 
defining, measuring and analysing rural areas in Central Serbia began in the middle of the $19^{\text {th }}$ century with KARADŽIĆ (1827), then continued through the work of KARIĆ (1887) and Novaković (1891). A new, more scientifically established approach to Serbian/Balkans' rural studies was given by CviJIĆ (1922). His work majorly contributed to establishing Serbian rural geography, but also had a significant influence on various European research communities dealing with rural studies. Besides Cvijić, a significant contribution was made by VukosaVlJević (1953), founder of rural sociology in Serbia, and KoJIć (1958).

The socialist period brought a new paradigm in comprehending rural and rurality. Despite Serbian scholars interpreted rural and rurality diversly, rural areas were usually observed through the urban - rural dichotomy. Some authors defined rural and rurality based on their traditional cultural background (StOJANOV 1996; BABIĆ 2000). Others interpreted rural and rurality using economy, agriculture in particular, emphasising the family farm as a key feature of rural structures (RADMANOvić 1999).

In general, rural was often identified as the residual to urban (RADMANOVIĆ 1999; VASILEVSKA 2006; BogdANOv 2007). This was typical not only for academia, but for the socialist development planning practice as well. It was a consequence of the prevailing socialist paradigm of social, economic and cultural development which was focused on industrial growth and urbanisation. As a result, the research of rural and rurality in the socialist Serbia was mainly focused on opportunities for urbanisation of rural areas, not only in terms of their infrastructural and economic development, but in a sense of diffusing the urban way of life. Thus, rural development has been considered as a second-class development topic or even reduced to the level of daily political disputes. Unlike urban settlements, rural areas were considered underdeveloped, socially unattractive and with insufficient potentials. Ever since, such has formed a tendency towards treating the rural as a social problem, not as a resource. In theory, it led to underdevelopment of the concepts of rural and rurality.

In (post)transitional Serbian society, rural areas are still habitually observed through the urban - rural dichotomy, merely as passive objects. The negative effects of such an approach are very much present. Even though diversified, rural areas in contemporary Serbia are generally marginalised and facing depopulation, economic underdevelopment, social exclusion, environmental underprotection, negative social labeling, structural isolation and organisational misbalance (Stojanov 1996; Todorović and DrobnJaković 2010; Drobnjaković 2015). Numerous research studies (Penev 1999; Stevanović 1999; Radovanović 2010; Cvejić et al. 2010; Drobnjaković 2019) have confirmed heterogeneity of rural areas and settlements in Serbia, especially in the region of Central Serbia. Such heterogeneity reflects at many levels (e.g. morphological, ecological, demographic, socio-economic, cultural and functional).

Additionally, rural diversification provoked several scientific attempts to establish rural typologies. Basically, there are two types of such typologies: The first type is based on distinct features of rural settlements (CVIJIĆ 1922; MACURA 1954; KoJIĆ 1958; RADOvanović 1965; Bukurov 1983; Stamenković and BaČević 1992; Simonović and Ribar 1993; ToŠić 1999; Stamenković 1999; Pavkov 2008), while the second type is shifted towards more comprehensive rural typologies based on contemporary understanding and methods for designating rural areas (ŠUvar and PULJIZ 1972; MerEdiTH 2006; ZAKić and Stojanović 2006; Bogdanov, Meredith and Efstratoglou 2008; Nuegovan, Pe- 
Janović and Petrović 2008; Mitrović 2015; Martinović and Ratkaj 2015). Current aspirations on the issue are marked by switching towards a greater complexity and interdisciplinarity, having in mind several major milestones (e.g. the concept of an integrated rural development, multifunctionality of agriculture and rural areas, polyvalence of the rural scene) (Drobnjaković, Spalević and Miletić 2016).

Contemporary (post)transitional Serbia is considered as a predominantly rural country. Unfortunately, there are no precise data on the issue - the share of rural areas varies from 67.4 percent (by the degree of urbanity) in the "Spatial Plan of the Republic of Serbia" (SPRS 2010), according to European legislation, through 85 percent based on population density with the threshold below 100 inhabitants $/ \mathrm{km}^{2}$ (European Commission 1997) or 90 percent with the threshold below 150 inhabitants $/ \mathrm{km}^{2}$ (OECD 1994) to as much as 96.2 percent of "other" settlements, according to the 2011 Census (SORS 2012a).

However, Serbia does not have established a unique rural typology. There were a few efforts on the matter (RAdovanović 1965; StOJILJKović and BošKović 2008; MARTINOVIĆ and RATKAJ 2015; DrobNJaKović 2019) and they form an important baseline for this research and attempt to establish relevant rural indicators. For example, the previous "Strategy of agricultural development of the Republic of Serbia" (SADRS 2005) takes into consideration rural indicators such as the active agricultural population and population density. The "National program of rural development of the Republic of Serbia" (Government RS 2011) distinguishes a set of relevant rural indicators - economic (per capita income), demographic (population density, population age, employment rate, employees by activity sector), agrarian (employment and income from the food industry, average size of agricultural households, the share of the protected forest cover, utilised agricultural land of high natural value, agricultural land for organic production), environmental (use of renewable energy sources) and service-related (tourism infrastructure, Internet use, income in services sector).

In the current "Strategy of agriculture and rural development of the Republic of Serbia 2014-2024" (SARDRS 2014), the issue of rural indicators hasn't been considered - the creators of the "Strategy" used national official census methodology. Unfortunately, according to it, there is no definition of rural settlements or rural areas - they have been classified as others (i.e. non-urban areas), according to the administrative criterion. The Census category of other settlements comprises of all settlements within rural areas and smaller municipal centres without urban character or urban plan, in accordance with the "Law on construction land" (Government RS 2001). Such solution is simply not functional, both for academia and planning practice as it disrupts full comprehension of diversity of contemporary Serbian rural areas.

In our study, we advocate that it is possible to determine a set of relevant indicators able to measure the degree of rurality and to track socio-spatial transformations between various areas/settlements. We have focused our analysis on the region of Central Serbia due to its remarkable mosaic structure of rural areas in terms of their population, economy features, land use patterns and quality of life (BogdanOv and BABOvić 2014; CVIJANOvić, Subić and Paraušić 2014; Mitrović 2015; Ševarlić 2015; Drobnjaković 2019). The selected region entails 63.2 percent of the total area of Serbia (without Kosovo and Metohija) and it is considered to be representative for the national scope analysis. 


\section{Study area and methodology}

The Republic of Serbia is traditionally divided into three main regions - Vojvodina, Central Serbia and Kosovo and Metohija (Fig. 1). Central Serbia covers almost $55967 \mathrm{~km}^{2}$ or three quarters of the total national territory. It consists of three statistical NUTS 2 regions (City of Belgrade, Šumadija and Western Serbia; South and East Serbia) and 18 districts (NUTS 3).

There are 4252 settlements in the observed area, of which 127 are designated as urban. 73 percent of the total Serbian population live in Central Serbia. The average population size of settlements in Central Serbia is 1258 inhabitants, while it is more than twice lower in the rural parts only - about 500. The average population density in Central Serbia is moderate (91 inhabitants $/ \mathrm{km}^{2}$ ), with significant differences between regions. While the highest number of population lives in Šumadija and Western Serbia region (1.924 million), the greatest population density is in the administrative region "City of Belgrade" ( 523 inhabitants $/ \mathrm{km}^{2}$ ), which is 7-9 times more than in the other two regions. The study area has a negative population growth ( -1.40 percent) and a pronounced socio-economic misbalance, which significantly impacts its settlements' characteristics and structure.

The settlements in Central Serbia are characterised by a significant heterogeneity. The whole area is represented by mixed topographical and hydrological patterns, from the plate in the northern part, through the hilly area of the Šumadija district to the prevailed mountain character of the south-eastern and south-western parts, with prominent river valleys in the whole area. Such a mixture reflects in agricultural diversity. Central Serbia is an extremely polarised area in population and economic sense. Misbalance in the population distribution is evident in the line North - South, or capital - other parts of the study area (1:3.2), as well as urban to rural area $(1.5: 1)$.

Also, municipalities in Central Serbia are unequally developed. Only six of $117 \mathrm{mu}-$ nicipalities are labelled as developed, and 19 municipalities are marked as devastated, with a development index lower than 50 percent of the Republic's average (Government RS 2004). At the same time, infrastructural and socio-cultural patterns show an uneven spatial distribution that is characterised, on the one hand, by areas close to significant development axes (with favourable accessibility and infrastructure), and, on the other, by peripheral areas with poor infrastructure and lack of the public services. The mosaic of settlements in Central Serbia justified the selection of the area and supported the initial hypothesis that rurality is characterised by the heterogeneity and that in defining and measuring the rurality, different dimensions of the rurality should be consulted.

The attempt to establish a set of rural indicators is based on the lowest-level of spatial units - settlements. Such enabled us to take into account all the local specifics of the analysed area. The analysis initially included all of 4127 other/non-urban settlements of Central Serbia, according to the official census methodology (SORS 2012a). Even though the consulted methodology has certain previously elaborated shortcomings, it was applied and considered relevant as it was used in the national census. Thus, it provided the most comprehensive data on settlements in the analysed area.

However, after thorough considerations, 262 settlements were excluded from the initial scope. We eliminated all urban settlements and municipal centres without urban character. Rural settlements in the Belgrade (capital city) region were also excluded due to their 


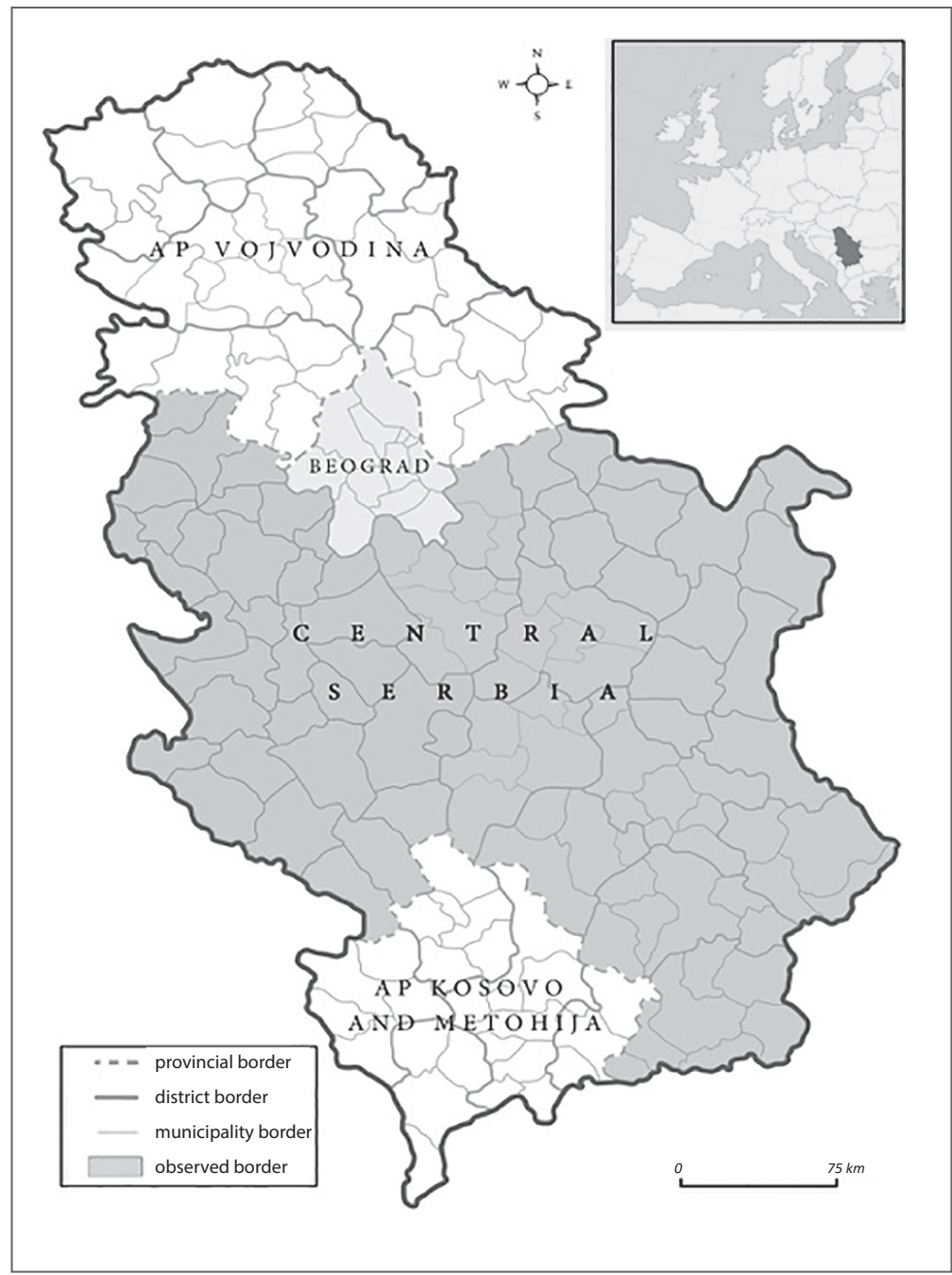

Source: Author: Milena PANIĆ

Figure 1: Central Serbia within the Republic of Serbia ${ }^{1)}$

significantly higher level of general development which potentially could disrupt data analysis. Also, 94 settlements of two municipalities at the very south-eastern part were reduced due to the uncompleted coverage of the population census. At last, 13 settlements were excluded due to the lack of relevant statistical data. As a result, we took into account data of 3977 rural settlements in Central Serbia (93.5 percent of the initial scope).

\footnotetext{
1) Note of the editor: The map is including the newly established state Republic of Kosovo, due to the reason that the independence of Kosovo from Serbia and its sovereignity are not accepted by the Serbian government.
} 
The empirical database for the analysis consists of vast and various data from:

- the National Population Census of 2011 (SORS 2012a; 2012b; 2013c; 2013d; 2014a; $2014 b ; 2014 c ; 2014 d ; 2014$ e) - e.g. total population, age structure, economic activity, income structure, daily commuters, education structure, etc.;

- the National Agricultural Census of 2012 (SORS 2013a; 2013b) - e.g. number of agricultural farms, utilised agricultural area, arable and non/arable agricultural land, farm land use, agricultural production structure, etc.

Also, relevant spatial data (e.g. settlement area, built-up area) were provided by the Republic Geodetic Authority (RGA 2012). The inventory of the public service facilities (e.g. elementary and secondary schools, ambulance, postal office, etc.) was compiled based on information collected in interviews with local authorities and surveys of the local population, and in accordance with official lists of the public amenities by relevant institutions as secondary sources (Institute of Public Health of Serbia; Ministry of Education, Science and Technological Development of the Republic of Serbia; The Post of Serbia).

The Analysed data referred to the period 2011-2012, as this time section included census years. Dynamic indicators were based on data from the period 1981-2011, as this time span referred to the period of post-socialist transition.

The preliminary list of 23 rural indicators was compiled in accordance with the relevant European legislation (OECD 1994; The Wye Group 2007; Eurostat 2015), national legislation, previously mentioned rural typologies and various recent researches (DAX and FisChER 2018; MurUA and FerRero 2019). Also, the list of rural indicators is arranged in line with the data collection methodology. Indicators were chosen to enable systematic representation of different attributes of rurality of settlements in Central Serbia. In this regard, the selected indicators are classified into three main groups:

a) demographic - this group of indicators outlined the basic characteristics of demographic structures of the rural population,

b) geospatial - indicators designated the main features of geospatial development of the analysed settlements,

c) socio-economic - this group of indicators described main elements of socio-economic development of the analysed settlements (Fig. 2).

We applied a quantitative approach in order to examine the identified indicators. The quantitative analytical method provided us with an opportunity for an objective designation of rural indicators. The process of determining the legitimacy of the preliminary indicators consisted of three phases. The first phase included a descriptive statistical analysis which was used to describe and summarise relevant data on selected indicators. Also, descriptive statistics enabled us to create a quantified concept of rural space in Central Serbia. The second phase comprised of correlation analysis in order to establish relations between the chosen indicators (hereby regarded as variables). The scatter diagram and Pearson's coefficient were used to identify linear correlations between the indicators/variable system, as well as its nature and extent. Finally, in the third phase the regression analysis was carried out; the significance of the regression model and the reliability of regression analysis in the specific case were tested using an F-test. 


\begin{tabular}{|c|c|}
\hline Demographic indicators & Geospatial indicators \\
\hline $\begin{array}{l}\text { - } \text { Population size } \\
\text { - Pre-school population (\%) } \\
\text { - Vitality index } \\
\text { - Elderly }(\%) \\
\text { - Population change rate } \\
\text { - }(1981-2011) \\
\text { - Population with university } \\
\text { - } \text { education }(\%) \\
\text { Population with second- } \\
\text { ary education }(\%)\end{array}$ & 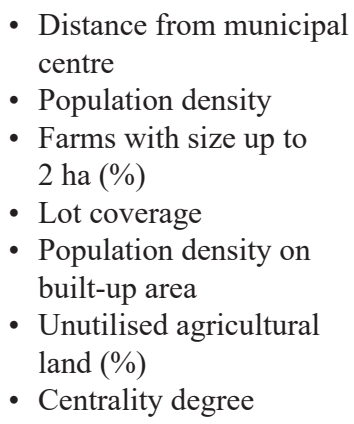 \\
\hline
\end{tabular}

Socio-economic indicators

- Single-member households $(\%)$

- Multi-member households (\%)

- Rural economy diversification

- Daily commuters (\%)

- Retired population (\%)

- Population receiving social support (\%)

- Long-term unemployment $(\%)$

- Economic dependency ratio

- Economic activity rate

Source: Authors' compilation

Figure 2: Preliminary list of rural indicators

The validity of the regression model for specific predictor indicators/variables was established, based on the non-standardised regression coefficient $(\beta)$ for the predictor variables. The influence of the individual predictor variables in the regression model was explained by the partial correlation. Quality assessment and the significance rate were based on the coefficient of determination ( $\mathrm{r}^{2}$ ) (ŽIzIĆ, LovRIĆ and PAVLIČIĆ 2001; LovRIĆ 2009; MILOVANOVIĆ 2013). In order to facilitate the interpretation, the coefficient of determination was shown. The software package SPSS (19.0) was used for data processing.

\section{Results and discussion}

\subsection{Description of rural settlements in Central Serbia using identified indicators}

As previously mentioned, rural areas in Central Serbia are distinctly heterogeneous. In order to ensure a better understanding and quantified description of the entire analysed area, we used descriptive statistics to determine the regularity of the set of the observed variables (Table 1).

The analysed data show that unfavorable demographic trends are common to the entire area of Central Serbia. Since the beginning of the 1980s, population in the analysed settlements declined for almost one fifth in average. The most intensive decline was recorded in the rural areas of the East and South Serbia region, particularly in its remote southern and eastern districts (more than -27 percent decrease in districts of Zaječar, Pirot, Toplica and Pčinja). On the other hand, the Belgrade region is characterised by the smallest population decrease (-1.89 percent). A similar tendency is also evident in many of the EU countries 
whereas "people have moved from rural, agricultural regions towards large cities (and their surrounding suburban areas)" (Eurostat 2019). However, rural depopulation is not evenly distributed among EU countries - it is more prevalent "in the EU-13 of central and eastern Europe with circa 60 percent of regions experiencing depopulation while, in the EU-15 of western Europe, just over 35 percent of rural regions are shrinking" (ESPON 2017). The average population size of rural settlements in Central Serbia was 499.43 inhabitants, which classified them as small rural settlements. This type of rural settlements prevailed in the whole area, except in the Belgrade region which was characterised by settlements with greater population size (1 863 on average).

The average value of the vitality index was below 1 , which indicates an intensive process of rural ageing - data showed that almost one third of the rural population in Central Serbia (30.3 percent) were elderly people older than 65 , while the share of the pre-schoolers ( $0-6$ years) was only 3.35 percent on average. The most unfavourable population age structure was registered in the East and South Serbia region, where 36.4 percent of population were elderly and only 2.6 percent of population were represented by pre-schooler contigent. Districts with most intensive population decline also recorded a significant ageing. The rural population in Central Serbia in general is in the stage of deep demographic old age. Negative population trends in the rural settlements of Central Serbia corresponded with the underdeveloped rural economy (few employment opportunities), lack of infrastructure (roads, sanitation and Internet connection), difficulties in accessing various social services and institutions (health service, education, cultural institutions, etc.). Likewise, according to Eurostat (2019), population ageing is the most evident in the "rural areas whose economies were centered on traditional activities" (e.g. mountainous areas of central France, Greece, north-western Spain, Portugal and the United Kingdom).

The age structure shaped household size. In the majority of rural settlements in Central Serbia, the single-member (mainly elderly) households accounted for one fourth of the samples. The share of households with multiple members significantly varied, ranging from 0 to the maximum of 68 percent. The largest share of single-member households was identified in the south-eastern districts of the area, which were majorly affected by negative demographic trends.

The unbalanced rural population distribution in Central Serbia is reflected in the distinct variability of population density. The rural settlements in Central Serbia are sparsely populated - average population density is only 57 inhabitants $/ \mathrm{km}^{2}$ - while half of the rural settlements in the area have a population density below 30 inhabitants $/ \mathrm{km}^{2}$. Those are mainly settlements in south-western and south-eastern uplands and/or in border zones. On the contrary, the average population density of rural settlements in the Belgrade region is on the threshold for rurality delimitation -150.7 inhabitants $/ \mathrm{km}^{2}$. A more representative indicator of the actual population density is the share of the population living in built-up areas. It indicates the concentration of inhabitants and the differentiation of settlements according to the degree of concentration or dispersion. It also enabled us to incorporate a spatial component into the analysis. The built-up areas of the rural part of Central Serbia have an average population density of 12.5 inhabitants/ar, in total. In general, rural settlements of the Belgrade region are densely populated, more than twice than other parts of 


\begin{tabular}{|c|c|c|c|c|c|c|c|c|}
\hline 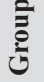 & Indicators & Mean & Min & Max & $\begin{array}{l}\text { Medi- } \\
\text { an }\end{array}$ & Mode & $\begin{array}{l}\text { St. } \\
\text { dev. }\end{array}$ & $\begin{array}{l}\text { Vari- } \\
\text { ance }\end{array}$ \\
\hline \multirow{7}{*}{ 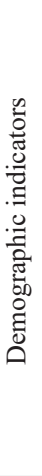 } & Population size, 2011 & 499.43 & 1 & 26,904 & 284 & 30 & 824.91 & 165 \\
\hline & Pre-school population (\%) & 3.35 & 0 & 21.62 & 3.29 & 0 & 2.42 & 72 \\
\hline & Vitality index & 0.94 & 0 & 28 & 0.79 & 0 & 0.92 & 99 \\
\hline & Elderly (\%) & 30.30 & 0 & 100 & 26.12 & 50 & 15.91 & 53 \\
\hline & Population change rate (1981-2011) & -19.09 & -63.85 & 33.69 & -17.62 & -39.34 & 16.14 & 85 \\
\hline & $\begin{array}{l}\text { Population with the university } \\
\text { education }(\%)\end{array}$ & 3.88 & 0 & 50 & 3.31 & 0 & 3.51 & 90 \\
\hline & $\begin{array}{l}\text { Population with secondary } \\
\text { education }(\%)\end{array}$ & 30.61 & 0 & 100 & 31.07 & 0 & 14.49 & 47 \\
\hline \multirow{6}{*}{ 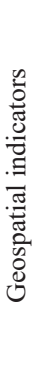 } & Distance from municipal center & 14.44 & 0.40 & 93 & 12 & 10 & 9.86 & 68 \\
\hline & Population density & 57.20 & 0.06 & $4,579.63$ & 29.80 & 3 & 147.15 & 257 \\
\hline & Farms with size up to 2 ha $(\%)$ & 43.18 & 0 & 100 & 41.18 & 50 & 21.56 & 50 \\
\hline & Lot coverage & 3.63 & 0.04 & 55.37 & 3.16 & 2.13 & 2.83 & 78 \\
\hline & $\begin{array}{l}\text { Population density on built-up area } \\
\text { (inh./ar) }\end{array}$ & 12.53 & 0.04 & 367.51 & 9.60 & 25.86 & 14.66 & 117 \\
\hline & Unutilized agricultural land (\%) & 8.30 & 0 & 72.36 & 5.35 & 0 & 8.99 & 108 \\
\hline \multirow{10}{*}{ 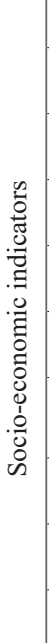 } & Centrality degree of settlement & 1.22 & 0 & 7 & 1 & 0 & 1.52 & 124 \\
\hline & Single-member households (\%) & 26.15 & 0 & 100 & 23.91 & 25 & 13.17 & 50 \\
\hline & Multi-member households (\%) & 11.04 & 0 & 68 & 9.82 & 0 & 9.02 & 82 \\
\hline & Diversification of rural economy (\%) & 6.89 & 0 & 100 & 4.17 & 0 & 9.84 & 143 \\
\hline & Daily commuters (\%) & 66.41 & 0 & 100 & 71.43 & 100 & 24.44 & 37 \\
\hline & Retired population (\%) & 30.54 & 0 & 100 & 26.82 & 33.33 & 14.68 & 48 \\
\hline & $\begin{array}{l}\text { Population receiving social } \\
\text { support }(\%)\end{array}$ & 2.80 & 0 & 50 & 1.91 & 0 & 3.29 & 117 \\
\hline & Long-term unemployment (\%) & 50.18 & 0 & 100 & 53.05 & 0 & 31.09 & 62 \\
\hline & Economic dependency ratio & 3.49 & 0 & 174 & 2.09 & 1 & 6.79 & 195 \\
\hline & Economic activity rate & 60.46 & 0 & 100 & 59.49 & 100 & 20.06 & 33 \\
\hline
\end{tabular}

Source: Calculations by authors

Table 1: Quantification of the socio-spatial features of rural settlements in Central Serbia 
the region. South-eastern districts of the area had the lowest concentration of the population in built-up areas.

The geospatial position and geospatial character indicated multiple variations among rural settlements. In previous studies (ŠEVARLIĆ 2015; SARDRS 2014), it was pointed out that agricultural land abandonment was one of the major rural geospatial features in Central Serbia. It is a consequence of unfavorable land quality and negative demographic and economic trends. At the EU level, a comparable trend is evident, especially in North and Northwest Spain and Poland, but also in several other post-socialist countries such as Romania, Latvia and Estonia (Perpiña CAstillo et al. 2018). However, data showed that the share of the social fallow (as an indicator of agricultural land abandonment) was not high -8.3 percent on average per settlement. Nevertheless, this indicator is characterised by considerable variability, as it ranges from 0 to 72 percent (in non-agricultural or demographical abandoned rural settlements).

As far as the size of agricultural households is concerned, there is a tendency towards enlargement of the utilised agricultural land per farm (Š́EvarLić 2015). However, small farms (up to 2 ha) still prevail (43 percent), which is a serious obstacle for increasing the efficiency of agriculture, especially on family farms (ČIKIĆ 2018). We found that a large portion of small farms and the share of unutilised agricultural land are in correlation, as the tendency of abandoning of agricultural land is more intensive in the districts where small farms prevailed (e.g. south-eastern districts of the Central Serbia).

Significant differences were observed among the settlements in terms of the rural population's socio-economic structure. On average, the active rural population accounted for 60 percent of the population aged 15-64 years. In some rural settlements, the share of active population was greater than the working-age population contingent, indicating prolonged economic activity of rural elderly, especially those active in farming. This is a result of an even now present traditional pattern of equalisation of period of the economic activity with the lifespan. In contemporary Serbian society, such pattern is formed due to agricultural labour force ageing. Also, it is supported by the exclusion of rural youth from the work process for the purpose of obtaining education, but also their lack of interest in farming. The active population was more numerous than the working-age population contingent particularly in the smallest rural settlements, which were the most severely affected by rural depopulation and ageing.

However, the unemployment rate of the rural population in Central Serbia was about 11 percent, with half of the unemployed who were long-term unemployed. In 53 percent of the observed rural settlements in Central Serbia, more than a half of the unemployed population was long-term unemployed. Accordingly, the dependency ratio of the rural population stood out as a relevant rural indicator. It is a ratio of the economic dependent and employed population. In the observed area, one employed person supports more than three economic dependent persons (e.g. unemployed, students, housewives, etc).

About 40 percent of the population of the analysed rural settlements of Central Serbia are involved in farming. However, the mode of this indicator was close to zero which designates that agriculture had a minor role as an income source. Such a result designates that those rural settlements lost their agrarian character. Under presented circumstances and in terms of an increased rural deprivation and poverty, settlements were identified as rural if 
the income of the retired and inactive population was important within the total income structure for meeting the basic life needs. Two relevant indicators were selected - share of retired population and share of population receiving social subsidies. The value of the first indicator was on average 30 percent, while the second indicator was significantly lower, about 2.8 percent on average; however, in some rural settlements, it reached up to 50 percent.

Only 6.9 percent of the rural population in Central Serbia was engaged in non-agricultural economic activities in the settlement where they were living which indicated a low rural economy diversification. On the other hand, the rural settlements with a higher degree of rural economy diversification were identified as potential generators of rural development as diversified rural economy creates various job opportunities and income sources. Accordingly, this indicator reflected the degree of settlement's development. The most diversified rural economy was recorded in the rural settlements of Belgrade region, which is the result of vicinity of the capital city and the attraction forces of the urban economy.

Three indicators were chosen to represent the human capital of rural settlements - educational structure, daily commuting of the rural population and social supra-structure. Characteristics of educational structure indicated moderate to low education potentials of the rural population in the Central Serbia. Only 3.8 percent of the rural population have university education. According to the indicator, rural settlements in Central Serbia were very heterogeneous: it was possible to find settlements without a single person with academic education (e.g. small and remote villages with mainly elderly population or farming population; villages with a high share of retired population and persons living on social subsidies); in contrast, there were also rural settlements where people with university degree accounted for between one fourth and half of the adult population. Those settlements are located mainly in the vicinity of regional centres. Mostly, such rural settlements were purely residential ("sleeping areas" for daily commuters). On the other hand, the share of the rural population with secondary education was significant - 30 percent on average, with a low variance.

Daily commuting is also an important element in the determination of the rurality degree as it indicates individual, but also group's mobility capacity (KAUFMANN, BERGMAN and JoYe 2004; ČIKIĆ and STOJŠIN 2017). Approximately, two-thirds of the rural population within the observed area commutes on daily basis. Nevertheless, the share of rural daily commuters varied greatly, depending on the rural settlement's remoteness and available infrastructure as well as on rural population's age and economic structure. In half of the observed rural settlements in Central Serbia, daily commuters accounted for more than 71 percent of total economically active population. A high portion of daily commuters indicated a low productivity of the rural economy as rural gentrification in Central Serbia is underrepresented. Also, the most of the rural dialy commuters were labour force with dominantly lower education (primary and secondary). A high portion of rural daily commuters was identified in the Belgrade region. This was an additional indicator of the low productivity of rural economy.

The social supra-structure (available public services and facilities) was one of the most relevant indicators in the conducted analysis as it reflects the centrality degree of the set- 
tlements (cf. Cloke 1983; Malić 1991; Marinković 2018; Drobnjaković 2019). First, the inventory of public social amenities and services was made, in terms of their number and importance according to the official categorisation. Afterwards, a quantitative evaluation of the settlements was conducted. Each settlement was assigned a certain value (ordinary) or rank depending on the number of social amenities and public services and their degree of significance. Settlements were ranked into eight categories, where zero was assigned to a settlement with lack of social supra-structure, and seven was the highest rank that a settlement could have (DrobnJaković 2019). Rural settlements in Central Serbia were assigned to ranks 1 or 2. That indicated that rural settlements in Central Serbia provided merely the basic public services (e.g. four years of primary schooling, ambulance). Favourable social supra-structure was found in rural settlements of the Belgrade region and in central parts of the area. In addition to the underdeveloped rural economy, under-availability of public services and facilities in rural settlements indicated a greater risk of social exclusion and, consequently, a lower quality of rural life.

\subsection{Measuring linear correlations between selected indicators}

The diversity of the analysed data confirmed that it was necessary to apply a comprehensive approach when studying rural settlements and to take into consideration the local features of the analysed territory. In order to establish a set of indicators suitable for determining the rurality degree, it was compulsory to prove the nature and strength of the relationship between demographic, socio-economic and geospatial indicators. In the second phase of analysis, such relationship was analysed by linear correlation analysis, using Pearson's coefficient. Since the limits of statistical significance are not strictly defined (LOVRIĆ 2009), the threshold of statistical significance in this study is taken to be the value of the correlation coefficient \pm 0.3 . The values below the determined threshold are very weak and could not be considered reliable for the conducted analysis. A weak correlation is indicated by correlation coefficients from \pm 0.3 to \pm 0.5 ; a medium by the values between \pm 0.5 and \pm 0.7 , and a strong correlation is indicated by values higher than \pm 0.7 .

Due to the great data heterogeneity, the correlation between indicators was usually insignificant or very low. This was caused by several factors: great heterogeneity of the analysed settlements in Central Serbia, the absence of or very low linear correlations of the observed phenomena, the overlapping and hidden impact of one variable under the influence of another, etc. A somewhat higher degree of significance was identified among demographic indicators (as they pointed out to similar trends). The strongest correlation is observed among variables that described the same population contingent (e.g. Retired population and Elderly, $\mathrm{r}=0.863$; Single-member households and Elderly, $\mathrm{r}=0.665$ ), or among indicators that designated the same phenomena (e.g. Population density and Lot coverage, $\mathrm{r}=0.677$; Elderly and Population change rate, $\mathrm{r}=-0.730$ ).

Moderate correlations were found among the following rural demographic indicators:

a) Population size with Population change rate and Population density $(\mathrm{r}=0.520)$, which was expected as Population size was used as an input to create other variables; 
b) Pre-school population with the Vitality index $(\mathrm{r}=0.612)$, the Multiple-member households $(\mathrm{r}=0.611)$ and Population change rate $(\mathrm{r}=0.451)$, describing demographic vitality of settlements; on the other hand, this indicator showed an inverse correlation with indicators such as Single-member households $(\mathrm{r}=-0.481)$, Elderly and Retired population $(\mathrm{r}=-0.564)$, as these indicators describe two opposite population contingents;

c) the Elderly showed inverted correlation with the Population with a secondary education $(\mathrm{r}=-0.615)$, indicating a diminished contingent of the working-age population;

d) the indicator Single-member households was directly correlated with the Retired population $(\mathrm{r}=0.619)$ and it showed an inverted correlation with the Multiple-member households $(\mathrm{r}=-0.561)$ and the Population change rate $(\mathrm{r}=-0.609)$;

e) the indicator Population with secondary education was directly correlated with the Lot coverage in rural settlements $(r=0.455)$ and demographic trends $(r=0.712)$, which indirectly indicated the vitality of the settlements.

Other correlations - displaying interrelations among the remaining indicators - were weak. For example, the indicator Distance of the settlement from the municipal centre showed an inverted correlation with the Population size, Daily commuters, Population with secondary and Population with university education and the Population change rate. This indicated the influence of the vicinity of an urban centre on the development of rural communities. The indicator Diversification of rural economy was directly correlated with the Settlements' centrality, Population with secondary education and the total Population size which reflected the development potentials and the rurality degree. The low values of Pearson's correlation coefficient showed insignificant relationship between the following indicators: Long-term unemployed and Population receiving social subsidies. Despite the very weak correlation, the aforementioned indicators were not initially excluded from further analysis because of their possible indirect influence and relevance for the research.

Before calculating Pearson's correlation coefficient, scatter diagrams were made for each indicator in order to determine the type (shape, direction and intensity) and nature of relationships among them. Generally, a weak linear correlation prevailed among the observed indicators. Stronger correlations are found among demographic indicators and those representing the same phenomena. However, absence of the correlation was observed between the Settlements centrality and the Long-term unemployed. In this specific case, the analysis of the correlation coefficient could not be taken as relevant.

On the other hand, the spatial dimension was incorporated into the analysis by observing a correlation coefficient among regions in Central Serbia. If the data set is larger, the variance of the observed indicators is greater, and the correlation is lower. Due to the heterogeneity and spatial differences, some rules could be noticed. For example, in all three statistical NUTS 2 regions of Central Serbia (City of Belgrade; Šmadija and Western Serbia; South and East Serbia) the strongest correlations were identified in the set of demographic variables or among those which were based on population data (Population density general and on built-up area, Retired population, etc.). On the other hand, a weak correlation was identified with the variables Long-term unemployed and Population receiving social subsidies, and a very weak correlation with the variables Unutilszed agricultural land and Economic dependency ratio. 
In this regard, the significant correlation between the Economic dependency ratio and other variables was registered only in the Belgrade region (the strongest with the variable Activity rate, $\mathrm{r}=0.815$ ), while in the other two regions it was insignificant. The Centrality degree showed low to moderate correlations in all three regions, but with the same pattern - positive correlation with Total population size and Diversification of the rural economy, but negative with Daily commuters.

Such conclusions were relevant for the analysis of spatial and socio-economic transformations of rural settlements. Likewise, the correlation of Daily commuters in the observed set of variables was higher in the Belgrade region, due to a tight relation with the capital and an intensive circulation of the population in this region, particularly with the variables: Centrality degree $(\mathrm{r}=-0.722)$, Diversification of rural economy $(\mathrm{r}=-0.692)$ and Distance from the urban center $(\mathrm{r}=-0.302)$.

Similar interrelations were expressed by the variable Diversification of the rural economy with mentioned variables among regions in the variable set. Significant correlation was identified in the Belgrade region and the region of Šumadija and Western Serbia, which are characterised by a more diversified rural economy. Besides the aforementioned variables, in the the region of Šmadija and Western Serbia positive correlations with education structure of the population were recognised (Population with university education: $\mathrm{r}=0.372$; Population with secondary education: $\mathrm{r}=0.376)$.

\subsection{Regression analysis}

In order to determine the nature of the interrelationships of the indicators and to avoid a possible overlapping of hidden ("masked") influences that could not be identified by the correlation analysis, multiple regression analysis was conducted. This analysis enabled us to estimate the dependency among the indicators by creating a regression model that described relationships among them. Indirectly, multiple regression analysis could also be used for forecasting and characterising the variation among the observed phenomena (ŽIŽIĆ et al. 2001). In this study, the regression analysis is strictly used to investigate the relationship between selected demographic, geospatial and socio-economic indicators of rural areas in Central Serbia.

The first step in regression analysis involved determining the dependent indicators and a set of predictor indicators. Based on theoretical backgrounds, empirical experience and the insight into the analysed sample group, three criterion indicators were identified: Population change (1981-2011), Economic dependency ratio and Population density in the built-up area. Those criterion indicators representatively illustrated the transformation of settlements in the posts-socialist period and crucially determined their rural character. Furthermore, three groups of predictors (see Table 3) were selected to explain the strength of effect on the given criterion indicators (Table 2).

The variance of the first criterion indicator - Population change (1981-2011) - was well explained by the regression model using the suggested set of predictors. Based on theoretical and empirical findings, 12 predictor variables were selected (Table 3). The correlation coefficient was high $(\mathrm{r}=0.81)$. The variability of the predictors explains 66.4 


\begin{tabular}{|l|c|c|c|c|}
\hline \multicolumn{1}{|c|}{ Criterion (dependent indicator) } & $\mathbf{R}$ & $\mathbf{R}^{\mathbf{2}}$ & Adjusted $\mathbf{R}^{\mathbf{2}}$ & $\mathbf{F}$ \\
\hline Population change rate (1981-2011) & .81542955 & .66492536 & .6638262 & 604.94 \\
\hline Economic dependency ratio & .48918669 & .23930362 & .23738557 & 124.76 \\
\hline Population density on built-up area & .71217505 & .50719331 & .50619975 & 510.48 \\
\hline
\end{tabular}

Source: Calculations by authors.

Table 2: Significance test of the regression model on criterion indicators

percent of dependent indicator's variance. As the value of the F-test is higher than zero and statically significant, the regression analysis is reliable in this case (Table 2). A moderate to high linear fitting is found based on the scatter plots. Consequently, the suggested regression model was accurate. The strongest, but negative effect of the linear correlation was observed with the Elderly, while weak correlations were found with the indicators that represented Size of farms (agricultural households) and the Settlement s centrality degree (Table 3).

In two out of the 12 predictors, the identified p-values are greater than 0.05 . As a result, they are not useful in explaining or predicting the variance of the criterion indicator. On the other hand, these variables reach statistically significant values of Pearson's correlation coefficient ( $\mathrm{r}$ ) with the selected criterion indicator, but, according to the partial correlation coefficient (Table 3), the relationships are masked by other disturbers, exogenous factors or interrelations with other indicators. The predictor Distance from the urban center showed very week influence on the variance $\left(r^{2}=10 \%\right)$, so it could not be considered as a useful predictor in this regression model.

The highest share of variance of the criterion indicator was explained by the variability of the predictor Small farms (by size) $\left(\mathrm{r}^{2}=89 \%\right)$. However, this was not a best predictor, due to the low linear fitting and a weak partial correlation. The predictor with the highest influence on the variance of the criterion indicator was the Elderly, which showed a significant association with the criterion indicator when the effects of other factors and the influence of other variables were eliminated. When estimating the coefficient of determination, important predictors in this model were also the Pre-schoolers $\left(\mathrm{r}^{2}=51 \%\right)$, with an effect that was determined by external factors; Single-member households $\left(\mathrm{r}^{2}=50 \%\right)$ and Population size in $2011\left(\mathrm{r}^{2}=43 \%\right)$, with a somewhat higher value of the partial correlation coefficient. The predictor Settlement's centrality degree was found to be significant but it was associated with the influence of other factors. The variance of the first criterion indicator - Population change rate (1981-2011) - was explained by the one fourth to one third variability of other selected predictors.

The variance of the second criterion indicator - Economic dependency ratio - was explained using the given regression model of ten predictor variables only with 23.7 percent. This outcome has the lowest effect (Table 2) due to the choice of predictors and their weak linear association with the criterion indicator, as observed in scatters plots. No correlation was found with five predictors, whereas there was a very weak and statistically insignificant correlation with three other predictors. This outcome was in accordance with the low value of Pearson's correlation coefficient between the observed variables. The 


\begin{tabular}{|c|c|c|c|c|c|c|c|c|}
\hline : & Predictors & $\boldsymbol{\beta}$ & $\begin{array}{l}\text { Partial } \\
\text { correla- } \\
\text { tion }\end{array}$ & $\begin{array}{c}\text { Semi- } \\
\text { partial } \\
\text { corr. }\end{array}$ & $\begin{array}{l}\text { Toler- } \\
\text { ance }\end{array}$ & $\mathbf{R}^{2}$ & $\begin{array}{c}\mathbf{t} \\
(3977)\end{array}$ & $\begin{array}{c}\text { p- } \\
\text { level }\end{array}$ \\
\hline \multirow{12}{*}{ 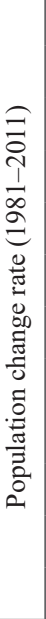 } & Elderly population $(\%)$ & -0.421 & -0.389 & -0.245 & 0.348 & 0.652 & -26.599 & 0.000 \\
\hline & Population size 2011 & 0.003 & 0.218 & 0.129 & 0.569 & 0.431 & 14.064 & 0.000 \\
\hline & Single-member households (\%) & -0.228 & -0.226 & -0.134 & 0.499 & 0.501 & -14.595 & 0.000 \\
\hline & Farm with size up to 2 ha (\%) & 0.150 & 0.114 & 0.066 & 0.109 & 0.891 & 7.194 & 0.000 \\
\hline & Distance from the urban centre & -0.111 & -0.153 & -0.090 & 0.900 & 0.100 & -9.750 & 0.000 \\
\hline & Daily commuters (\%) & 0.057 & 0.130 & 0.076 & 0.773 & 0.227 & 8.223 & 0.000 \\
\hline & Population density & 0.010 & 0.126 & 0.073 & 0.677 & 0.323 & 7.970 & 0.000 \\
\hline & Unutilised agricultural land (\%) & -0.140 & -0.114 & -0.066 & 0.722 & 0.278 & -7.224 & 0.000 \\
\hline & Settlement's centrality degree & 0.365 & 0.049 & 0.028 & 0.681 & 0.319 & 3.094 & 0.002 \\
\hline & Multi-member households (\%) & 0.034 & 0.023 & 0.013 & 0.499 & 0.501 & 1.450 & 0.147 \\
\hline & Vitality index & 0.243 & 0.017 & 0.010 & 0.500 & 0.500 & 1.068 & 0.285 \\
\hline & Pre-schoolers (\%) & 0.227 & -0.009 & -0.005 & 0.488 & 0.512 & 2.862 & 0.004 \\
\hline \multirow{10}{*}{ 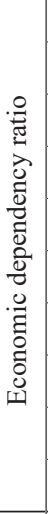 } & Vitality index & 0.025 & 0.023 & 0.020 & 0.631 & 0.369 & 1.454 & 0.146 \\
\hline & Diversification of rural economy (\%) & 0.056 & 0.056 & 0.049 & 0.790 & 0.210 & 3.564 & 0.000 \\
\hline & Daily commuters $(\%)$ & 0.022 & 0.023 & 0.020 & 0.787 & 0.213 & 1.427 & 0.154 \\
\hline & Retired population $(\%)$ & 0.274 & 0.230 & 0.206 & 0.564 & 0.436 & 14.886 & 0.000 \\
\hline & Population receiving social subsidies $(\%)$ & 0.113 & 0.123 & 0.108 & 0.921 & 0.079 & 7.824 & 0.000 \\
\hline & Long-term unemployed (\%) & -0.062 & -0.067 & -0.059 & 0.900 & 0.100 & -4.231 & 0.000 \\
\hline & Population with university education ( $\%)$ & -0.046 & -0.044 & -0.038 & 0.686 & 0.314 & -2.770 & 0.006 \\
\hline & Population with secondary education (\%) & -0.155 & -0.122 & -0.107 & 0.476 & 0.524 & -7.715 & 0.000 \\
\hline & Economic activity rate & -0.325 & -0.337 & -0.312 & 0.919 & 0.081 & -22.514 & 0.000 \\
\hline & Unemployment rate & 0.169 & 0.176 & 0.156 & 0.849 & 0.151 & 11.261 & 0.000 \\
\hline \multirow{8}{*}{ 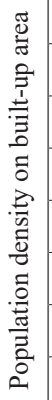 } & Population size 2011 & 0.157 & 0.168 & 0.120 & 0.585 & 0.415 & 10.744 & 0.000 \\
\hline & Pre-schoolers (\%) & 0.119 & 0.131 & 0.092 & 0.603 & 0.397 & 8.297 & 0.000 \\
\hline & Settlement's centrality degree & 0.033 & 0.042 & 0.029 & 0.776 & 0.224 & 2.633 & 0.008 \\
\hline & Multi-member households (\%) & 0.159 & 0.173 & 0.123 & 0.602 & 0.398 & 11.065 & 0.000 \\
\hline & Distance from the urban centre & -0.077 & -0.105 & -0.074 & 0.915 & 0.085 & -6.632 & 0.000 \\
\hline & Population density & 0.611 & 0.504 & 0.409 & 0.449 & 0.551 & 36.734 & 0.000 \\
\hline & Farm with size up to 2 ha $(\%)$ & 0.194 & 0.245 & 0.178 & 0.835 & 0.165 & 15.942 & 0.000 \\
\hline & Lot coverage & -0.286 & -0.275 & -0.201 & 0.490 & 0.510 & -17.992 & 0.000 \\
\hline
\end{tabular}

Source: Elaborated by authors (software package: SPSS 19.0)

Table 3: Regression analysis of criterion indicators and their predictors 
low relationship also indicated the low values of the partial correlation coefficient in the regression analysis.

However, the F-value was higher than zero $(\mathrm{F}=124.76)$ and, in this case too, the regression model was accurate. The testing of the significance of the regression coefficient showed that two predictors - Vitality index and Daily commuters - should be excluded from this regression model, as they did not show any significant correlation (Table 3). The best effect in this model was shown by two predictors: Population with secondary education $\left(\mathrm{r}^{2}=52 \%\right)$, which was due to the partial and symbiotic association with other indicators and Retired population $\left(\mathrm{r}^{2}=44 \%\right)$, which showed the strongest partial correlation with the criterion indicator in the observed group. Although the correlation with the Economic activity rate is statistically significant, the outcome of the regression analysis shows that the variance of the criterion indicator poorly explained the variability of the predictors $\left(\mathrm{r}^{2}=8 \%\right)$. The predictors Population with university education $\left(\mathrm{r}^{2}=31 \%\right)$ and Diversification of rural economy $\left(r^{2}=21 \%\right)$ influenced the variability of the criterion, though with significant interrelations with other indicators. On the other hand, two predictors - Long-term unemployed $\left(\mathrm{r}^{2}=10 \%\right)$ and Population receiving social subsidies $\left(\mathrm{r}^{2}=\right.$ $7.9 \%$ ) express very week influence on the variance due to insignificant linear correlation, so they could be considered as irrelevant or unsufficient for explaining these phenomena.

The third criterion indicator in the suggested regression model - Population density in the built-up area - showed a high association with the predictor variables $(\mathrm{R}=0.71)$. Half of the criterion variance (Adj. $\mathrm{R}^{2}=50.6 \%$ ) was explained by the variability of eight chosen predictors (Table 2 and Table 3 ). The testing of the significance of the regression analysis $(F=510.48)$ confirmed its accuracy (Table 2$)$. The selection of predictors was based on the assumption that the value of the criterion depended on the intensity and changes of the Lot coverage, Population size and the overall Population density, but in a longterm it could also be affected by indicators such as the Pre-schoolers and Multi-member households. Also, we have assumed that rural settlements with a higher centrality degree have a higher population concentration in the built-up area. The remaining two indicators were selected as a measure of the influence of peripherality on the population density or dispersion, and the size of agricultural households was used as an indicator of land use (small farms are more presented in urban areas). The last indicator indicated types of land use in the vicinity of densely populated rural areas. Another predictor-Distance from the urban center - was not very useful in explaining the variance of the criterion $\left(\mathrm{r}^{2}=8.5 \%\right)$ in this regression model.

As observed in the scatter diagram, the criterion indicator was linearly associated with the selected predictors. The strongest correlation was observed with the variables Population density (46\%) and Population size in 2011 (27\%), while other predictors showed weaker correlations. Those relations between criterion indicator and predictors were represented with $r$ values. In the given regression model, all predictor variables were proven to be accurate, based on t-test performed of the regression coefficients. The greatest share of the variance was explained by the following predictors: a) Population density $\left(\mathrm{r}^{2}=55\right.$ $\%$ ) which directly affected the criterion indicator and achieved a significant partial correlation coefficient; b) Lot coverage $\left(\mathrm{r}^{2}=51 \%\right)$ and c) Population size in $2011\left(\mathrm{r}^{2}=41 \%\right)$, the influence of which was also determined by other indicators. The predictors that indirectly 
influenced the variance of the criterion indicator also had an important effect (circa $40 \%$ ), particularly on Population density in the built-up area. The significance of other variables was not negligible, but it was determined by external factors.

After the analyses, it could be concluded that four indicators - Vitality index, Long-term unemployed, Population receiving social subsidies and Distance from urban centre - failed to explain the selected criterions. Consequently, the set of 19 indicators is proven to be relevant for describing and analysing socio-spatial aspects of the rurality of settlements in Central Serbia.

\begin{tabular}{|c|c|}
\hline Demographic indicators & Geospatial indicators \\
\hline $\begin{array}{l}\text { - Population size, } 2011 \\
\text { - Pre-schoolers (\%) } \\
\text { - Elderly population (\%) } \\
\text { - Population change rate } \\
\text { (1981-2011) } \\
\text { - Population with university } \\
\text { education (\%) } \\
\text { - Population with second- } \\
\text { ary education (\%) }\end{array}$ & $\begin{array}{l}\text { - Population density } \\
\text { - Farms with size up to } \\
2 \text { ha }(\%) \\
\text { - Lot coverage } \\
\text { - Population density on } \\
\text { buit-up area } \\
\text { - Unutilised agricultural } \\
\text { land (\%) } \\
\text { - Centrality degree of } \\
\text { settlement }\end{array}$ \\
\hline
\end{tabular}

\begin{tabular}{|l|}
\hline Socio-economic indicators \\
\hline - Single-member house- \\
holds (\%) \\
- Multi-member households \\
$(\%)$ \\
- Rural economy diversifi- \\
cation \\
- Daily commuters (\%) \\
- Retired population (\%) \\
- Economic dependency \\
ratio \\
\hline
\end{tabular}

Source: Authors' compilation

Figure 3: Final list of rural indicators

\section{Conclusions}

Based on the presented results, it can be concluded that the selected list of rural indicators is proven to be sensitive enough to enable a thorough description of analysed settlements in Central Serbia. It provided us with sufficient insight into the main features of the rural character of the analysed settlements. Also, the selected indicators are in accordance with the available data which facilitate the description of rural settlements in Central Serbia.

Further analyses showed interrelations among the selected indicators and their impact on the rurality of settlements in Central Serbia. However, generally low correlations prevailed in the set of selected indicators, which was due to the great heterogeneity of the analysed settlements. Stronger correlations are found among demographic indicators and those indicators representing the same phenomena.

Three most important attributes of rural settlements - Population change rate (19812011), Economic dependency ratio and Population density in the built-up area - were selected as criterion indicators for regression analysis. The first attribute - Population change rate (1981-2011) - was best explained by the selected predictors. As expected, it was inten- 
sively affected by demographic indicators (e.g. age structure). Nevertheless, the Population change rate (1981-2011) was also determined by Settlement's centrality degree (the settlements with a higher centrality degree are more vital and have greater population size), and Small farms ( up to $2 \mathrm{ha}$ ) which indicated higher exposure to negative demographic changes.

The second criterion indicator - Economic dependency ratio - was poorly explained in the given regression model of ten predictors. It was mostly explained by the changes in the Population 's economic activity and Retired population. However, in association with other external indicators, the Education level of rural population (acting inversely) and the Diversification of rural economy are considered significant for the changes of the criterion indicator as they reflected the economic potential of rural settlements. Therefore, they were considered very important in determining the rurality degree.

The third criterion indicator - Population density in the built-up area - was proven to be a criterion that can be fully explained by the changes in the assumed set of eight indicators. The most important indicators that directly affected this criterion were Population size and Lot coverage, but also some demographic indicators (e.g. Settlement's centrality degree, Daily commuters). It has been confirmed that these factors mostly affected the concentration of population in rural settlements and determined the areas that are more suitable to be populated or those that have achieved a greater social and economic development.

Four indicators were eliminated based on the given statistical analysis - Vitality index, Long-term unemployed, Population receiving social subsidies and Distance from urban center - due to weak correlations in the variable set and poor influence on the criterions' variance. The verified set of 19 indicators is a major step in making an effort to identify different forms of rurality and types of rural settlements in Central Serbia. By establishing an adequate set of rural indicators in Serbia and performing of a rural typology, the great benefit could be achieved not only for academia and scientific understanding of the analysed socio-spatial rural transformations, but also for the practical efforts to identify features of rural areas as an important resource for rural development.

\section{Acknowledgement}

This paper is a part of the projects III47007 and III46006, both financed by the Ministry of Education, Science and Technological Development of the Republic of Serbia (2011-2020).

\section{References}

BABIĆ G. (2000): Duh i atmosfera tradicionalnog sela [The spirit and atmosphere of the traditional village]. In: Zbornik radova Etnografskog instituta [Proceedings of the Ethnographic Institute of the Serbian Academy of Science and Arts], 49, pp. 27-34.

Bengs Ch., Schmidt-Thоме K. (eds.) (2003): ESPON 2006 Programme / Urban-rural Relations in Europa. Third Interim Report - Executive Summary. Helsinki: Centre for Urban and Regional Studies, Helsinki University of Technology. 
Bogdanov N. (2007): Mala ruralna domaćinstva u Srbiji i ruralna nepoljoprivredna ekonomija [Small rural households in Serbia and rural non-agricultural economy]. Belgrade: UNDP.

Bogdanov N., Meredith D., Efstratoglou S. (2008): A Typology of Rural Areas in Serbia. In: Economic Annals, 177, pp. 7-29.

Bogdanov N., BABović M. (2014): Radna snaga i aktivnosti poljoprivrednih gazdinstava [Labour force and activities of agricultural holdings]. Belgrade: Statistical Office of the Republic of Serbia.

Bukurov B. (1983): Geografske osnove postanka i razvoja naselja u Vojvodini [Geographical baselines of origin and development of settlements in Vojvodina]. In: Glas odeljenja prirodno-matematičkih nauka Srpske akademije nauka i umetnosti [Publications of the Department of Natural and Mathematical Sciences of the Serbian Academy of Sciences and Arts] 334 (49), pp. 112-116.

ČIIIĆ J. (2017): Transformacija i (re)brendiranje ruralnog prostora [Transformation and (re)branding of rural space]. In: Agroekonomika, 46 (76), pp. 23-34.

ČıкIĆ J. (2018): Porodična gazdinstva na raskršću: izazovi i mogućnosti biološke, ekonomske i socijalne reprodukcije [Family farms at a crossroads: challenges and opportunities for biological, economic and social reproduction]. Novi Sad: Faculty of Philosophy.

ČÍrıć J., StoJšın S. (2017): Dnevne migracije žena u Vojvodini [Daily commuting of female population in Vojvodina]. In: Sociološki pregled [Sociological Review], 51 (2), pp. 236-254.

Cloke P. J. (1983): An Introduction to Rural Settlement Planning. London: Routledge Revivals.

Cloke P. J. (2006): Conceptualizing Rurality. In: Cloke P., Marsden T., Mooney P. H. (eds.): Handbook of Rural Studies. London: Sage Publications, pp. 18-28.

Cvejić S., Babović M., Petrović M., Bogdanov N., Vuković O. (2010): Socijalna isključenost u ruralnim oblastima Srbije [Social exclusion of rural areas in Serbia]. Belgrade: UNDP.

Cvijanović D., Subić J., PARAušić V. (2014): Poljoprivredna gazdinstva prema ekonomskoj veličini i tipu proizvodnje u Republici Srbije [Agricultural farms by economic size and type of production in the Republic of Serbia]. Belgrade: Statistical Office of the Republic of Serbia.

CviJić J. (1922): Balkansko poluostrvo i južnoslovenske zemlje - Osnove antrpologeografije, knjiga 1 [Balkan Peninsula and South Slavic Countries - fundamentals of anthropogeography, Book 1]. Belgrade: Državna štamparija Kraljevine Srba, Hrvata i Slovenaca [State Printing House of the Kingdom of Serbs, Croats and Slovenes].

Dax T., Fischer M. (2018): An Alternative Policy Approach to Rural Development in Regions Facing Population Decline. In: European Planning Studies, 26 (2), pp. 297-315.

Drobnjaković M. (2015): Certain Aspects of Rural Planning in Serbia. In: Journal of the Geographical Institute "Jovan Cvijić", 65 (2), pp. 163-182.

DrobNJAKović M. (2019): Razvojna uloga ruralnih naselja centralne Srbije [The development role of the rural settlements in Central Serbia]. Belgrade: Geographical Institute "Jovan Cvijić" of the Serbian Academy of Science and Arts (= Posebna izdanja [Special Issues], 95).

Drobnjaković M., Spalević A., Miletić R. (2016): Development of Scientific Approaches in the Geography of Settlements in Serbia. In: Petrović A., Jović V. (eds.): 150th Anniversary of Jovan Cvijić's birth. Belgrade: Geographical Institute "Jovan Cvijić" of the Serbian Academy of Science and Arts, pp. 441-459.

ESPON (2017): Policy Brief - Shrinking Rural Regions in Europe. Luxembourg: ESPON EGTC.

European Commission (1997): AGENDA 2000. For a Stronger and Wider Union. Luxembourg: Office for Official Publications of the European Communities (= Bulletin of the European Union, 5/97).

Eurostat (2010): A Revised Urban-rural Typology. In: Eurostat Regional Yearbook 2010. Luxembourg: Publications Office of the European Union, pp. 239-253. 
Eurostat (2015): Urban-rural Typology Update. - https://ec.europa.eu/eurostat/statistics-explained/ index.php?title=Archive:Urban-rural_typology update (last access: Nov. 20, 2020).

Eurostat (2019): Eurostat Regional Yearbook. 2019 edition. Luxembourg: Publications Office of the European Union.

Gallent N., Juntti M., Kidd S., Shaw D. (2008): Introduction to Rural Planning. London: Routledge, Taylor \& Francis Group.

Government of the Republic of Serbia (2001): Law on Construction Land. In: Official Gazette, No. 23/01. Belgrade: Government of the Republic of Serbia.

Government of the Republic of Serbia (2004): Decree on Criteria and Indicators for Determining Devastated Areas of the Republic of Serbia. In: Official Gazette, No. 58/04. Belgrade: Government of the Republic of Serbia.

Government of the Republic of Serbia (2011): National Program for Rural Development of the Republic of Serbia. In: Official Gazette, No. 5/11. Belgrade: Government of the Republic of Serbia.

HALFACREe K. (1993): Locality and Social Representation: Space, Discourse and Alternative Definitions of the Rural. In: Journal of Rural Studies, 9 (1), pp. 23-37.

Harrington V., O’Donoghue D. (1998): Rurality in England and Wales 1991: A Replication and Extension of the 1981 Rurality Index. In: Sociologia Ruralis, 38 (2), pp. 178-203.

Hoggart K., Buller H., Black R. (1995): Rural Europe, Identity and Change. London: Arnold.

KARADŽıĆ V. S. (1827): Geografičesko-statističesko opisanje Srbije 1827 [Geographical and statistical description of Serbia 1827]. In: KARADŽIĆ V. S.: Danika. Zabavnik za godinu. Reprinted 1965: Sabrana dela Vuka Karadžića [Collected Works of Vuk Karadžić], Volume 8: Danica (1826, 1827, 1828, 1829, 1834). Belgrade: Prosveta, pp. 127-176.

KARIĆ V. (1887): Srbija - opis zemlje, naroda i države [Serbia - description of the country, people and state]. Belgrade: Kraljevsko-srpska drž. štamparija [Royal-Serbian State Printing House].

Kaufmann V., Bergman M., Joye M. (2004): Motility: Mobility as Capital. In: International Journal of Urban and Regional Research, 28 (4), pp. 745-756.

KoJIć B. (1958): Seoska arhitektura i rurizam - teorija i elementi [Rural architecture and rurism theory and elements]. Belgrade: IP Građevinska knjiga.

Lovrić M. (2009): Osnovi statistike [Basics of statistics]. Kragujevac: University of Kragujevac, Faculty of Economics.

Lukić A. (2010): O teorijskim pristupima ruralnom prostoru [On theoretical approaches to rural space]. In: Hrvatski geografski glasnik [Croatian Geographical Bulletin], 72 (2), pp. 49-75.

LuKıć A. (2012): Mozaik izvan grada - tipologija ruralnih i urbaniziranih naselja Hrvatske [Mosaic outside the city - a typology of rural and urbanised settlements in Croatia]. Samobor: Meridijani.

MACURA M. (1954): Kriterijumi za razgraničavanje gradskog i seoskog stanovništva [Criteria for distinguishing urban and rural population]. In: Statistička revija [Statistical Review], 3-4, pp. 371-376.

MaLIĆ A. (1991): Osnovne razvojne karakteristike centralnih naselja nižeg reda u Republici Hrvatskoj [Basic development characteristics of central places with lower centrality degree in Croatia] In: Acta Geographica Croatica, 26, pp. 59-64.

MARINKović V. (2018): Identifikacija prostorno-razvojnih trendova hrvatskih otoka analizom opremljenosti naselja centralnim funkcijama [Spatial development processes of Croatian islands - the analysis of island settlements in terms of the quantity and quality of their central functions]. In: Sociologija i prostor [Sociology and Space], 56, 210 (1), pp. 3-34. 
Martinović M., RatKaj I. (2015): Sustainable Rural Development in Serbia: Towards a Quantitative Typology of Rural Areas. In: Carpathian Journal of Earth and Environmental Sciences, 10 (3), pp. 37-48.

Meredith D. (2006): Identification of Rural Regions for Planning Purposes in Serbia. Dublin: Rural Economy Research Centre (= Working Paper Series, 06-WP-RE-16).

Milovanović B. (2013): About Hidden Influence of Predictor Variables - Suppressor and Mediator Variables. In: Journal of the Geographical Institute "Jovan Cvijić", 63 (2), pp. 1-10.

Mitrović M. (2015): Sela u Srbiji - promene strukture i problemi održivog razvoja [Villages in Serbia - Changes in the structure and sustainable development issues]. Belgrade: Statistical Office of the Republic of Serbia.

Murdoch J., Pratt C. (1993): Rural Studies: Modernism, Postmodernism and the "Post-rural". In: Journal of Rural Studies, 9 (4), pp. 411-427.

Murua J. R., Ferrero A. M. (2019): Talking About Regional Resilience: Evidence from Two Formerly Rural Spanish Regions. In: European Planning Studies, 27 (11), pp. 2312-2328.

Njegovan Z., Pejanović R., Petrović D. (2008): Regionalisation of Rural Areas in AP Vojvodina Problems in Definiton of Rural Areas. In: Agroekonomika, 39-40, pp. 5-17.

NovaKović S. (1891): Selo [Village]. Belgrade: Serbian Royal Academy (= Glas Srpske akademije nauka [Veröffentlichungen der Serbischen Akademie der Wissenschaften], 24).

OECD (1994): Creating Rural Indicators for Shaping Territorial Policy. Paris: OECD Publications and Information Centre.

Openshaw S. (1985): Rural Area Classification Using Census Data. In: Geographia Polonica, 51, pp. 285-300.

Paquette S., Domon G. (2003): Changing Ruralities, Changing Landscapes: Exploring Social Recomposition Using a Multi-scale Approach. In: Journal of Rural Studies, 19 (4), pp. 425-444.

PAvkov S. (2008): Podela naselja na seoska i gradska [Division of settlements into rural and urban]. pp. 174-181 In: Zbornik radova sa savetovanja „Popis 2011“ - Popis stanovništva, domaćinstava i stanova [Proceedings of the Conference "Census 2011” - Census of Population, Households and Dwellings]. Belgrade: Statistical Office of the Republic of Serbia.

Penev G. (1999): Prirodno kretanje seoskog stanovništva Jugoslavije sa posebnim osvrtom na fertilitet početkom 1990-ih [Natural change of the rural population of Yugoslavia with an emphasis on fertility in the early 1990s]. In: Stanovništvo [Population], 37 (1-4, Tematski broj - Demografske karakteristike seoskog stanovništva Jugoslavije [Thematic Issue - Demographic Characteristics of ther Rural Population of Yugoslavia]), pp. 45-72.

Perpiña Castillo C., Kavalov B., Diogo V., Jacobs-Crisioni C., Batista e Silva F., Lavalle C. (2018): Agricultural Land Abandonment in the EU within 2015-2030. Seville: Joint Research Center (= JRC Working Papers, JRC113718).

Phillips M., Fish R., Agg J. (2001): Putting Together Ruralities: Towards a Symbolic Analysis of Rurality in the British Mass Media. In: Journal of Rural Studies, 17 (1), pp. 1-27.

RADMANović D. (1999): Ruralnost i urbanizovanost Srbije i starost stanovništva i poljoprivrednika [Rurality and urbanisation of Serbia and aging of the population and farmers]. In: MACURA M. (ed.): Socijalne i ekonomske mere u prilog rađanja [Social and Economic Measures in Favour of Birth]. Belgrade: Serbian Academy of Science and Arts, pp. 233-250 (= Demografski zbornik, knjiga V [Demographic Proceedings, Vol. 5].

RADOVANOVIĆ M. (1965): Metodološka pitanja klasifikacije seoskih naselja sa posebnim osvrtom na Srbiju [Methodological issues of the classification of rural settlements with special reference to Serbia]. In: Zbornik radova Geografskog instituta Prirodno-matematičkog fakulteta [Proceedings of the Geographical Institute of the Faculty of Science], 12, pp. 97-110. 
RADOVANOviĆ V. (2010): Integralni ruralni razvoj: ka skladnijem regionalnom razvoju [Integral rural development: towards more harmonious regional development]. In: Zbornik Matice srpske za društvene nauke [Matica Srpska Journal of Social Sciences], 132, pp. 41-53.

RGA - Republic Geodethic Authority (2012): Površine atara naselja [Areas of settlements]. Belgrade: RGA.

SADRS (2005): The Strategy of Agricultural Development of the Republic of Serbia. In: Official Gazette, No. 78/05. Belgrade: Government of the Republic of Serbia.

SARDRS (2014): Strategy of Agriculture and Rural Development of the Republic of Serbia 20142024. In: Official Gazette, No. 85/14. Belgrade: Government of the Republic of Serbia.

ŠEvarLić M. (2015): Popis poljoprivrede 2012. godine - Poljoprivredno zemljište [Census of Agriculture 2012 - Agricultural land]. Belgrade: Statistical Office of the Republic of Serbia.

Simonović Đ., Ribar M. (1993): Uređenje seoskih teritorija i naselja - urbanizacija sela [Arrangement of rural territories and settlements - urbanisation of rural settlements]. Belgrade: "IBI" Inženjering i projektovanje ["IBI" Engineering and Design].

SORS (2012a): 2011 Census of Population, Households and Dwellings in the Republic of Serbia Age and Sex. Belgrade: Statistical Office of the Republic of Serbia.

SORS (2012b): Vital Statistics, Special Data Processing. Belgrade: Statistical Office of the Republic of Serbia.

SORS (2013a): Census of Agriculture 2012 - Agriculture in the Republic of Serbia, Book 1. Belgrade: Statistical Office of the Republic of Serbia.

SORS (2013b): Census of Agriculture 2012 - Agriculture in the Republic of Serbia, Book 2. Belgrade: Statistical Office of the Republic of Serbia.

SORS (2013c): 2011 Census of Population, Households and Dwellings in the Republic of Serbia Educational Attainment, Literacy and Computer Literacy. Belgrade: Statistical Office of the Republic of Serbia.

SORS (2013d): 2011 Census of Population, Households and Dwellings in the Republic of Serbia - Households According to the Number of Members (Belgrade: Statistical Office of the Republic of Serbia).

SORS (2014a): 2011 Census of Population, Households and Dwellings in the Republic of Serbia - Population According to the Source of Income, Special Data Processing. Belgrade: Statistical Office of the Republic of Serbia.

SORS (2014b): 2011 Census of Population, Households and Dwellings in the Republic of Serbia - Industry, Special Data Processing. Belgrade: Statistical Office of the Republic of Serbia.

SORS (2014c): 2011 Census of Population, Households and Dwellings in the Republic of Serbia Commuting, Special Data Processing. Belgrade: Statistical Office of the Republic of Serbia.

SORS (2014d): 2011 Census of Population, Households and Dwellings in the Republic of Serbia Population According to the Education Level, Special Data Processing. Belgrade: Statistical Office of the Republic of Serbia.

SORS (2014e): 2011 Census of Population, Households and Dwellings in the Republic of Serbia - Economic Activity, Special Data Processing. Belgrade: Statistical Office of the Republic of Serbia.

SPRS (2010): The Spatial Plan of the Republic of Serbia 2010-2014-2021. In: Official Gazette, No. 24/10. Belgrade: Government of the Republic of Serbia.

STAMENKović S. (1999): Naučna polazišta proučavanja aktuelne ruralne situacije i seoskih naselja kao mogućih centara razvoja Srbije [Scientific starting points for studying the current rural situation and rural settlements as possible centres of development of Serbia]. In: Stanovništvo [Population], 37 (1-4, Tematski broj - Demografske karakteristike seoskog stanovništva Jugoslavije [Thematic Issue - Demographic Characteristics of ther Rural Population of Yugoslavia]), pp. 185-194. 
Stamenković S., BaČEvić M. (1992): Geografija naselja [Geography of settlements]. Belgrade: Faculty of Geography, University of Belgrade.

Stevanović R. (1999): Seoska naselja Jugoslavije: broj, prostorni razmeštaj i struktura prema demografskoj veličini [Rural settlements of Yugoslavia: number, spatial distribution and structure according to demographic size.]. In: Stanovništvo [Population], 37 (1-4, Tematski broj - Demografske karakteristike seoskog stanovništva Jugoslavije [Thematic Issue - Demographic Characteristics of ther Rural Population of Yugoslavia]), pp. 25-44.

Stojanov M. (1996): Selo kao jedinica ruralnosti i okvir balansiranja potencijala razvoja [The village as a unit of rurality and a framework for balancing development potentials]. In: Zbornik Matice srpske za društvene nauke [Matica Srpska Journal of Social Sciences], 101 pp. 7-21.

StojILJKović D., BošKović O. (2008): Metodološke napomene u vezi sa identifikacijom ruralnih područja i utvrđivanjem indikatora za merenje stepena ruralnosti [Methodological notes regarding the identification of rural areas and the establishment of indicators for measuring the degree of rurality]. In: Agroekonomika, 37-38, pp. 48-56.

Šuvar S., PuljIz V. (eds.) (1972): Tipologija ruralnih sredina u Jugoslaviji: zbornik teorijskih i metodoloških radova [Typology of rural areas in Yugoslavia: Collection of theoretical and methodological papers]. Zagreb: SOUR za sociologiju sela Instituta za ekonomiku poljoprivrede i sociologiju sela [SOUR for Rural Sociology of the Institute of Agricultural Economics and Rural Sociology].

The Wye Group (2007): Handbook Rural Households' Livelihood and Well-Being - Statistics on Rural Development and Agriculture Household Income. New York / Geneva: United Nations.

Todorović M., Drobnjaković M. (2010): Peripheral Rural Areas in Serbia - The Result of Unbalanced Regional Development. In: Geographica Timisiensis, 19 (2), pp. 207-219.

Tošść B. (2011): Osnove ruralnog planiranja [Basics of rural planning] Belgrade: University of Belgrade, Faculty of Geography.

Tošrć D. (1999): Prostorno-funkcijski odnosi i veze u nodalnoj regiji Užica [Spatial-functional relations and connections in the nodal region of Užice] ( $\mathrm{PhD}$ dissertation). Belgrade: University of Belgrade, Faculty of Geography.

VASILEvSKA L. (2006): Ruralni razvoj u regionalnim okvirima [Rural development in regional frameworks]. Belgrade: Zadužbina Andrejević [Andrejević Endowment].

Vukosavljević S. (1953): Istorija seljačkog društva [History of the peasant society]. Belgrade: Štamparija i knjigoveznica Srpske akademije nauka [Printing House of the Serbian Academy of Sciences]). Reprinted in: Mitrović et al. (eds.) (2012): Sabrana dela [Collection of Papers], Vol. 1-6. Belgrade: Službeni glasnik.

Woods M. (2005): Rural Geography: Processes, Responses and Experiences in Rural Restructuring. London: SAGE Publications.

Woods M. (2011): Rural. London and New York: Routlege.

Woods M. (2012): New Directions in Rural Studies? In: Journal of Rural Studies, 28 (1) pp. 1-4.

Zakić Z., Stojanović Ž. (2006): Regionalne specifičnosti i održivi razvoj ruralne Srbije [Regional specifics and sustainable development of rural Serbia]. In: Ekonomika poljoprivrede [Agricultural Economic], 53 (2), pp. 129-140.

Zlatić M. (1993): Prostorno-ekološka dimenzija odnosa selo-grad [Spatial-ecological dimension of the rural - urban relationship]. In: Sociologija sela - Journal of Rural Sociology, 31 (3-4), pp. 57-64.

Žıžić M., Lovrić M., PAvLIČIĆ D. (2001): Metodi statističke analize [Methods of statistical analysis]. Belgrade: University of Belgrade, Faculty of Economy. 